\title{
Identification of the bacterial endosymbionts of the marine ciliate Euplotes magnicirratus (Ciliophora, Hypotrichia) and proposal of 'Candidatus Devosia euplotis'
}

\author{
Claudia Vannini, Giovanna Rosati, Franco Verni and Giulio Petroni \\ Dipartimento di Etologia, Ecologia, Evoluzione dell'Università di Pisa, Pisa, Italy
}

Correspondence

Claudia Vannini

c.vannini@deee.unipi.it

\begin{abstract}
This paper reports the identification of bacterial endosymbionts that inhabit the cytoplasm of the marine ciliated protozoon Euplotes magnicirratus. Ultrastructural and full-cycle rRNA approaches were used to reveal the identity of these bacteria. Based on analysis of $16 \mathrm{~S}$ rRNA gene sequences, evolutionary trees were constructed; these placed the endosymbiont in the genus Devosia in the $\alpha$-Proteobacteria. The validity of this finding was also shown by fluorescence in situ hybridization with a Devosia-specific oligonucleotide probe. Differences at the 16S rRNA gene level (which allowed the construction of a species-specific oligonucleotide probe) and the peculiar habitat indicate that the endosymbiont represents a novel species. As its cultivation has not been successful to date, the provisional name 'Candidatus Devosia euplotis' is proposed. The species- and group-specific probes designed in this study could represent convenient tools for the detection of 'Candidatus Devosia euplotis' and Devosia-like bacteria in the environment.
\end{abstract}

Endosymbiotic bacteria in ciliates have mainly been studied by protozoologists, using morphological and functional approaches. They were originally described as cytoplasmic or nuclear particles, designated by a single Greek letter (Preer et al., 1974; Nobili et al., 1976; Rosati et al., 1976; Heckmann et al., 1983; for a review, see Görtz, 2002), and most of them have not yet been redescribed or given a binomial name. The only exceptions are represented by the following genera with validly published names, which inhabit different species of Paramecium: Caedibacter (Preer \& Preer, 1982) (five species), Lyticum (Preer \& Preer, 1982) (two species), Pseudocaedibacter (Quackenbush, 1982) (three species) and Holospora (ex Hafkine, 1890; Gromov \& Ossipov, 1981) (four species), and by a single Euplotes endosymbiont that was redescribed as Polynucleobacter necessarius (Heckmann \& Schmidt, 1987). Molecular

Published online ahead of print on 9 January 2004 as DOI 10.1099/ ijs.0.02759-0.

\footnotetext{
Abbreviation: FISH, fluorescence in situ hybridization.

The GenBank/EMBL/DDBJ accession numbers for the 16S rRNA gene sequences of 'Candidatus Devosia euplotis' from Euplotes magnicirratus strains LIV5, CO and CAMP4.4 are AJ548825, AJ548823 and AJ548824, respectively. The accession number for the 16S rRNA gene sequence of Devosia riboflavina DSM $7230^{\top}$ is AJ549086. The accession numbers for the 18S rRNA gene sequences of Euplotes magnicirratus strains LIV5 and CAMP4.4 are AJ549209 and AJ549210, respectively.

A complete similarity matrix and a colour version of Fig. 3 are available as supplementary material in IJSEM Online.
}

phylogenetic affiliation is available for an even smaller number of ciliate bacterial symbionts (Amann et al., 1991; Springer et al., 1993, 1996; Beier et al., 2002).

Beier et al. (2002) found that the two Caedibacter species so far characterized do not belong to the same subclass of proteobacteria, despite their morphological and functional similarity. This indicates that both morphological and molecular approaches are needed for satisfactory identification of endosymbionts.

In the present study, the identity and phylogenetic affiliation of an as-yet-undescribed symbiont of the marine species Euplotes magnicirratus was investigated by electron microscopy and the full-cycle rRNA approach. This cycle includes comparative $16 \mathrm{~S}$ rRNA gene sequence analysis and detection of the endosymbionts within their host cells by fluorescence in situ hybridization (FISH), using group- and species-specific, 16S rRNA-targeted oligonucleotide probes (Amann et al., 1991, 1995; Petroni et al., 2000).

These analyses showed that the endosymbiont is a novel species and was the same in all E. magnicirratus strains examined, despite their different geographical provenance. Comparative phylogenetic analysis indicated that this species could be included in the genus Devosia in the $\alpha$-Proteobacteria. Cultivation of these bacteria has not been successful to date and we therefore propose the provisional status Candidatus for this bacterial endosymbiont: 'Candidatus Devosia euplotis'. 
Three ciliate strains of different geographical origin were studied: LIV5 from the Ligurian Sea (Italy), CO from the Caribbean Sea (Colombia) and CAMP4.4 from the Sardinian Sea (Italy). By morphological observations and characterization of their 18S rRNA gene, they were all identified as E. magnicirratus. Clonal cultures were obtained from cells isolated from the marine samples and maintained in artificial sea water (salinity, $33 \%$ ) at $20{ }^{\circ} \mathrm{C}$. Ciliates were fed regularly with pure cultures of the nanoflagellate Dunaliella tertiolecta [for details, see Dini \& Nyberg (1994)].

Ciliate morphology was studied by using scanning and transmission electron microscopy, according to protocols used for other marine ciliates (Modeo et al., 2003).

Host and symbiont DNA extraction was performed by following the method of Wisotzkey et al. (1990) with slight modifications. Amplification of the $18 \mathrm{~S} \mathrm{rDNA}$ of E. magnicirratus strains was carried out by using the forward primer 18S F9 (Medlin et al., 1988) and the reverse primer 18S R1513 Hypo (Petroni et al., 2002). 16S rRNA genes of bacterial endosymbionts and of Devosia riboflavina DSM $7230^{\mathrm{T}}$ (Nakagawa et al., 1996) were amplified by using primers that were designed specifically for the $\alpha$ Proteobacteria subclass: forward, $16 \mathrm{~S}$ alfa F19a (5'-CCTGGCTCAGAACGAACG-3') and reverse, 16S alfa R1517 (5'-TGATCCAGCCGCAGGTTC- $3^{\prime}$ ). In order to obtain higher specificity, a 'touchdown' PCR (Don et al., 1991) was performed. Amplified and purified fragments were sequenced directly in both directions with the same primers that were used for amplification and with proper internal primers for the ciliate 18S rRNA gene sequence (Rosati et al., 2004) or the bacterial $16 \mathrm{~S}$ rRNA gene sequence (16S F7a: 5'-AGAGTTTGATCCTGGCTCA-3'; 16S F515 ND: 5'-GTGCCAGCAGCCGCGGT-3'; 16S F1099 ND: 5'GCAACGAGCGCAACCC-3'; 16S F343 ND : 5'-TACGGGAGGCAGCAG-3'; 16S F785 ND: 5' - GGATTAGATACCCTGGTA-3'; 16S R785 ND: 5'-TACCAGGGTATCTAATCC-3'; 16S R515 ND: 5' -ACCGCGGCTGCTGGCAC-3'; 16S R1522a: 5'-GGAGGTGATCCAGCCGCA-3').

Sequences were aligned by using the sequence editor and aligner from the ARB program package (Ludwig \& Strunk, 1997). In a preliminary analysis, sequences were added by using interactive parsimony to a general tree that comprised over 10000 bacterial species. Further phylogenetic analyses were performed with different subsets of closely related species. Some sequences of unidentified organisms that shared $>95 \%$ similarity with those of the endosymbionts were also included; only almost-complete sequences were included in analyses. Two filters were used to selectively remove or retain the more variable positions, before performing the phylogenetic analysis: filter bact_rr5_nov98 and filter alp_rr5_nov98 (Ludwig \& Strunk, 1997). Phylogenetic analyses were performed as described previously (Petroni et al., 2002). The two filters were used for each reconstruction method. Topologies of obtained trees were compared to recognize stable nodes (Ludwig et al., 1998b).
E. magnicirratus starved cells that belonged to the three strains and bacterial cells from growth media were fixed as described elsewhere (Petroni et al., 2003). In situ hybridization was performed according to Manz et al. (1992) without formammide in the hybridization buffer. In order to identify the endosymbiont group, the following oligonucleotide probes were used: ARCH915 (Stahl \& Amann, 1991), EUB338 (Amann et al., 1990), ALF1b, BET42a, GAM42a, (Manz et al., 1992) and one probe that is specific for most members of the $\delta$-Proteobacteria (Amann et al., 1995). Devosia group probe Dev_819 (5'-CCAACGGCTAGCTCTCAT-3') and 'Candidatus Devosia euplotis' probe DevEup_993 (5'-AAGTCGTCCTGGTATGTC-3') were designed to hybridize to variable regions of the obtained sequence of endosymbiont $16 \mathrm{~S}$ rRNA by using the special option of the ARB package, then refined and synthesized according to Petroni et al. (2003). Their specificity was checked with the probe-match tool from the ARB package (Ludwig \& Strunk, 1997). Both probes were checked on E. magnicirratus bearing symbionts and on D. riboflavina DSM $7230^{\mathrm{T}}$ (Nakagawa et al., 1996). Double hybridizations of species-specific probe DevEup_993 together with eubacterial universal probe EUB338 (Amann et al., 1990) or $\alpha$-subclass-specific probe ALF1b (Manz et al., 1992) were carried out, in order to exclude the presence of other eubacterial endosymbionts.

Starved E. magnicirratus cells were filtered and concentrated. They were then rapidly surface-sterilized with streptomycin $\left(400 \mathrm{mg} \mathrm{l}^{-1}\right)$ and washed with sterilized sea water. A suspension with sterilized, distilled water was sufficient to obtain osmotic lysis of the cells. The homogenate was then transferred to culture media and incubated at 28 and $20^{\circ} \mathrm{C}$. Growth attempts of endosymbionts were performed on the following media: nutrient agar and broth (Difco) with $\mathrm{KH}_{2} \mathrm{PO}_{4}\left(0 \cdot 45 \mathrm{~g} \mathrm{l}^{-1}\right)$ and $\mathrm{Na}_{2} \mathrm{HPO}_{4} \cdot 12 \mathrm{H}_{2} \mathrm{O}$ ( $\mathrm{pH} 6 \cdot 8)$, tryptone soya agar and broth (Oxoid) and marine agar and broth (Difco). The presence of E. magnicirratus symbionts was checked regularly every week for 1 month by in situ hybridization with the species-specific probe DevEup_993.

The three Euplotes strains used in this study have been assigned to E. magnicirratus, based on analysis of the morphological characters that are generally used to distinguish Euplotes species: size, shape, number of dorsal kineties, cirral arrangement and argyrome pattern on the dorsal surface (dargyrome). The assignment was congruent with the results obtained by comparative analysis of $18 \mathrm{~S}$ rRNA gene sequences. Both the newly determined sequences of CAMP4.4 and LIV5 are identical to the already published E. magnicirratus CO strain $18 \mathrm{~S}$ rRNA gene sequence (Petroni et al., 2002; GenBank accession no. AJ305250).

Morphologically identical bacterial endosymbionts were found in all specimens examined at the ultrastructural level, independent of the strain they belonged to (CO, LIV5 or CAMP4.4). In all cases, bacteria were distributed equally throughout the cytoplasm and were contained 


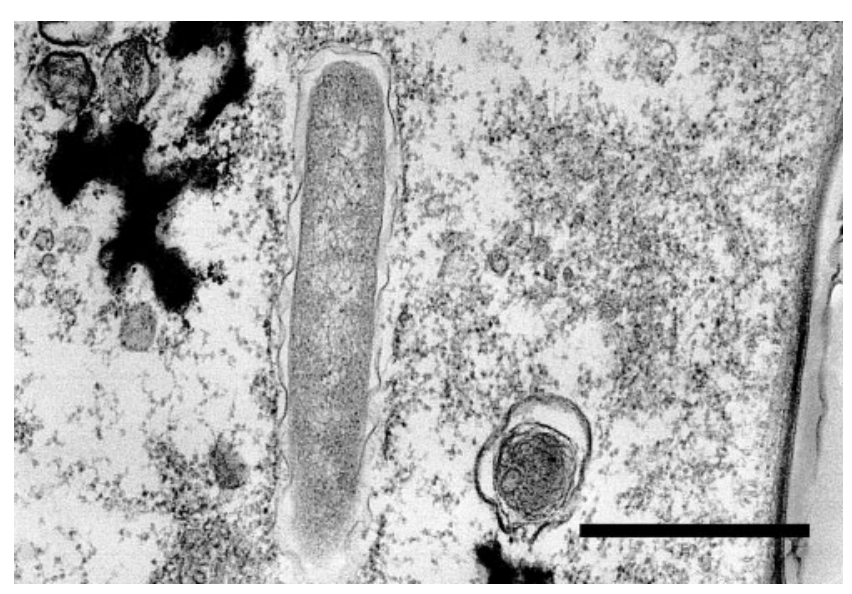

Fig. 1. Electron micrograph of 'Candidatus Devosia euplotis' in Euplotes magnicirratus. Bacteria are contained individually in small cytoplasmic vacuoles. Bar, $1 \mu \mathrm{m}$.

individually in vacuoles (symbiosomes), which probably originated from the host rough endoplasmic reticulum. This can be inferred by the presence of numerous ribosomes on their external surface (Fig. 1). The symbionts are rod-shaped bacteria, $0.5 \mu \mathrm{m}$ wide and up to $2.5 \mu \mathrm{m}$ long, that possess two membranes. The innermost membrane is adherent to the protoplasm; the outermost appears wavy and, at some points, contacts the membrane of the vacuole. Flagella are not present. The protoplasm is rich in ribosomes; dense nucleoids were not observed. The bacteria divide by transverse binary fission, accompanied by division of the vacuole to result in separate enclosure of each new bacterium.

The almost-complete $16 \mathrm{~S}$ rRNA gene sequence (1422 bp) of D. riboflavina DSM $7230^{\mathrm{T}}$ was determined; six nucleotide differences were observed from the originally described sequence (Nakagawa et al., 1996). Almost full-length sequences (1423 bp) of the bacterial endosymbiont $16 \mathrm{~S}$ rRNA gene were obtained from the three strains of E. magnicirratus. Validity of the sequences was confirmed by the positive results of in situ hybridization, performed with the DevEup_993 probe (see below). The sequences from strains CO and LIV5 are identical and differ by a single nucleotide substitution (position 592, relative to Escherichia coli 16S rRNA) from that obtained from strain CAMP4.4. This means that, despite their different geographical origin, endosymbionts of the three strains can reasonably be assigned to the same bacterial species. This species can now be added to the short list of molecularly characterized ciliate endosymbionts.

Endosymbionts of E. magnicirratus belong to the $\alpha$ subclass of the Proteobacteria. The sequences share rather low similarity with those of Holospora obtusa $(82.7 \%)$ and Caedibacter caryophilus $(85.7 \%)$, the only two described symbionts of ciliates that belong to the same subclass of proteobacteria. Similarity towards two bacteria of the genus Devosia, family Hyphomicrobiaceae, order 'Rhizobiales', is surprisingly high $(96 \cdot 2$ and $96.9 \%)$. The complete similarity matrix is available as supplementary data in IJSEM Online. The genus Devosia, proposed by Nakagawa et al. (1996), currently includes two species: $D$. riboflavina (Nakagawa et al., 1996), formerly Pseudomonas riboflavina, isolated from soil, and Devosia neptuniae, a nitrogen-fixing legume endosymbiont (Rivas et al., 2002, 2003). A value of $95 \%$ similarity between $16 \mathrm{~S}$ rRNA gene sequences is widely accepted to circumscript a genus of bacterial organisms (Ludwig et al., 1998b; Rosselló-Mora \& Amann, 2001), whilst a similarity value of $97 \%$ has been proposed as a critical boundary for species level (Stackebrandt, 2000; Ludwig \& Klenk, 2001; Rosselló-Mora \& Amann, 2001). On this basis, the endosymbiont of E. magnicirratus can be assigned to the genus Devosia, but the differences shown at the 16S rRNA gene level and its peculiar habitat suggest that it could represent a novel species.

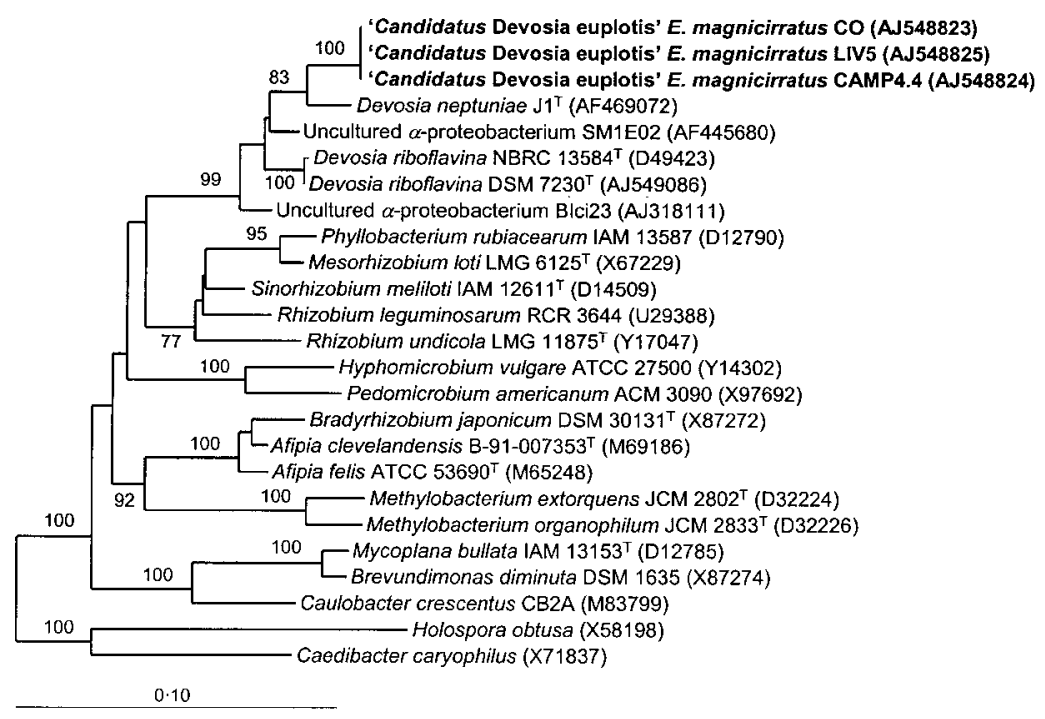

Fig. 2. Maximum-parsimony tree, inferred from 16S rRNA gene sequences by using filter alp_rr5_nov98. Numbers at bifurcations represent bootstrap values on 1000 pseudoreplicates (values $<70 \%$ are not shown). Branch-length was calculated with the parsimony interactive tool from the ARB package. Bar, 10 nucleotide substitutions in $100 \mathrm{nt}$. 
Phylogenetic analysis strongly confirmed these results (Fig. 2). Obviously, E. magnicirratus symbionts form a steady cluster and their association within the Devosia-like clade is highly supported, regardless of the reconstruction method and filter set used. Sequences of uncultured proteobacteria from different habitats also belong to the same group, suggesting that the genus Devosia could be broader and more diversified than considered previously. As already stressed by Nakagawa et al. (1996), the Devosialike cluster occupies an independent position in the $\alpha$ Proteobacteria and it is constantly associated with the included species of the rhizobia group in all trees calculated, although these associations are not supported by high bootstrap values.

The preliminary use of oligonucleotide probes for Archaea and the major subclasses of Proteobacteria revealed that the E. magnicirratus endosymbionts belong to the $\alpha$-Proteobacteria.

Comparison with all 16S rRNA gene sequences in the ARB database confirmed the specificity of the two designed probes. The Dev_819 probe detects all Devosia species, E. magnicirratus endosymbionts and all uncultured organisms that are related closely to the described Devosia species. No extra-target-group organisms were recognized by this probe; therefore, Dev_819 can be considered as an efficient and satisfactory tool for the detection of Devosia-like bacteria. DevEup_993 matched only the three endosymbiont sequences and this indicated its high specificity.

In situ hybridization confirmed these results. Dev_819 hybridized both with endosymbionts from the three strains of ciliate and with D. riboflavina DSM $7230^{\mathrm{T}}$. DevEup_993 gave a positive result only with ciliate endosymbionts (Fig. 3), whereas there was no detectable signal with $D$. riboflavina. This shows the different specificity of the designed probes, which allows discrimination at the species level within the genus as it is at present. As already stated by Ludwig et al. (1998a), the use of an appropriate set of oligonucleotide probes can represent a good and useful tool for rapid identification of bacteria at different taxonomic levels (Amann \& Schleifer, 2001). Finally, double hybridization performed with probes DevEup_993 and EUB338 or ALF1b excluded the presence of other $\alpha$ proteobacterial endosymbionts and, reasonably, of other eubacteria.

Any attempt to grow the symbionts in liquid or solid nutrient broth with added phosphates, a classical culture medium that is also suitable for the related species $D$. riboflavina, failed both at $20^{\circ} \mathrm{C}$ and at higher temperature $\left(28^{\circ} \mathrm{C}\right)$. The same negative results were obtained with tryptone soya agar and broth, as well as with marine agar and broth. These results suggest that endosymbionts of $E$. magnicirratus may have particular metabolic needs, therefore it is likely that they are hardly cultivable with standard cultivation techniques.

Morphological and molecular identities indicate that the
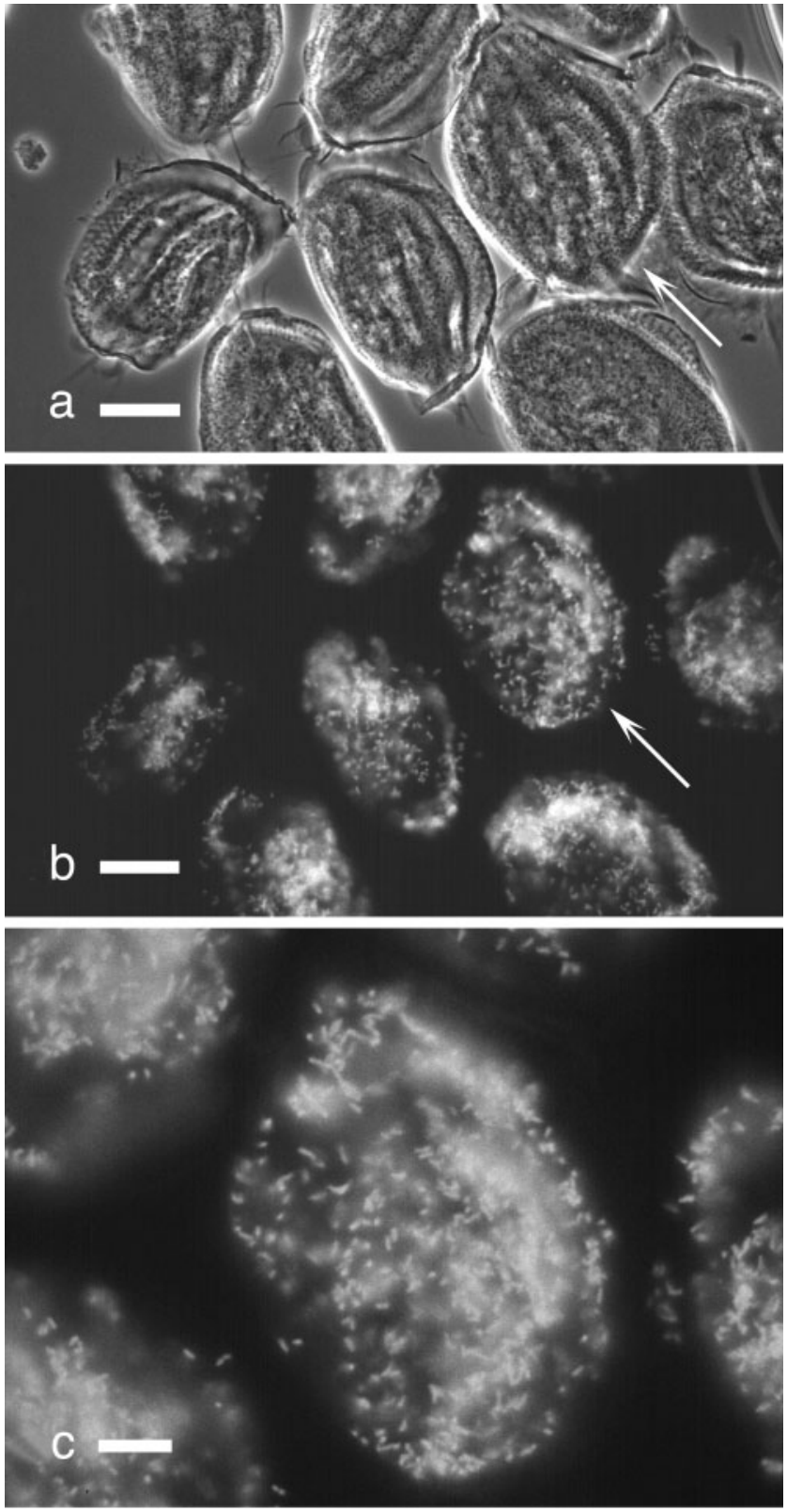

Fig. 3. FISH, demonstrating the identity of 'Candidatus Devosia euplotis' by using species-specific bacterial probe DevEup_993. (a) Phase-contrast; (b) corresponding fluorescent picture. Bars, $20 \mu \mathrm{m}$. Arrows indicate the host cell in (c), which shows the bacterium at higher magnification. Bar, $10 \mu \mathrm{m}$. A colour version of this figure is available as supplementary material in IJSEM Online.

endosymbionts of the three E. magnicirratus strains analysed here belong to the same species. E. magnicirratus is a cosmopolitan, sand-welling ciliate and the strains used were collected in geographical regions as far apart as the Mediterranean and Caribbean Seas. The symbionts were also maintained for years in laboratory cultures. As far as we know, similar symbionts have not been found in 
Euplotes-related species that share the same habitat as E. magnicirratus. Therefore, this symbiotic relationship appears to be permanent and species-specific. Phylogenetic analysis assigned the E. magnicirratus endosymbionts to the genus Devosia. Until we succeed in cultivation or additional phenotypic data become available, we assign them the provisional status Candidatus, as proposed by Murray \& Schleifer (1994) and implemented by Murray \& Stackebrandt (1995). Based on our characterization, we designate the symbiont as 'Candidatus Devosia euplotis'.

Moreover, we provide two new probes for the rapid and unambiguous recognition of this novel Candidatus species (DevEup_993) and the whole Devosia-like group of cultured and uncultured organisms (Dev_819).

\section{Description of 'Candidatus Devosia euplotis'}

'Candidatus Devosia euplotis'. The generic name is that of the genus to which, according to phylogenetic analysis, the species was assigned; the specific name is taken from the genus of the ciliate host: Euplotes Ehrenberg, 1830.

The 16S rRNA gene sequence obtained from symbionts of E. magnicirratus strain LIV5 from the Ligurian Sea (Italy) was chosen as the reference sequence.

'Candidatus Devosia euplotis' [( $\alpha$-Proteobacteria $)$ NC; NA; $\mathrm{R}$ (approx. $0.5 \mu \mathrm{m}$ wide and up to $2.5 \mu \mathrm{m}$ long); NAS (GenBank/EMBL no. AJ548825), oligonucleotide sequence complementary to unique region of $16 \mathrm{~S}$ rRNA 5'-AAGTCGTCCTGGTATGTC-3'; S (Euplotes magnicirratus, cytoplasm)]. Vannini et al., this study.

\section{Acknowledgements}

This study was supported by MURST. We thank A. Schena and L. Modeo for assistance in culturing and electron microscopic analysis and S. Gabrielli for photographic work. S. Bucci and M. Ragghianti are gratefully acknowledged for providing equipment and assistance for the fluorescence microscopy.

\section{References}

Amann, R. \& Schleifer, K.-H. (2001). Nucleic acid probes and their application in environmental microbiology. In Bergey's Manual of Systematic Bacteriology, 2nd edn, pp. 67-82. Edited by D. R. Boone, R. W. Castenholz \& G. M. Garrity. New York: Springer.

Amann, R. I., Krumholz, L. \& Stahl, D. A. (1990). Fluorescentoligonucleotide probing of whole cells for determinative, phylogenetic, and environmental studies in microbiology. J Bacteriol 172, 762-770.

Amann, R., Springer, N., Ludwig, W., Görtz, H.-D. \& Schleifer, K.-H. (1991). Identification in situ and phylogeny of uncultured bacterial endosymbionts. Nature 351, 161-164.

Amann, R. I., Ludwig, W. \& Schleifer, K. H. (1995). Phylogenetic identification and in situ detection of individual microbial cells without cultivation. Microbiol Rev 59, 143-169.

Beier, C. L., Horn, M., Michel, R., Schweikert, M., Görtz, H.-D. \& Wagner, M. (2002). The genus Caedibacter comprises endosymbionts of Paramecium spp. related to the Rickettsiales (Alphaproteobacteria) and to Francisella tularensis (Gammaproteobacteria). Appl Environ Microbiol 68, 6043-6050.

Dini, F. \& Nyberg, D. (1994). Adolescence and the reversibility of maturity in Euplotes crassus. J Eukaryot Microbiol 41, 373-380.

Don, R. H., Cox, P. T., Wainwright, B. J., Baker, K. \& Mattick, J. S. (1991). 'Touchdown' PCR to circumvent spurious priming during gene amplification. Nucleic Acids Res 19, 4008.

Gromov, B. V. \& Ossipov, D. V. (1981). Holospora (ex Hafkine 1890) nom. rev., a genus of bacteria inhabiting the nuclei of paramecia. Int $J$ Syst Bacteriol 31, 348-352.

Görtz, H.-D. (2002). Symbiotic associations between ciliates and prokaryotes. In The Prokaryotes: an Evolving Electronic Resource for the Microbiological Community, 3rd edn (http://141.150.157.117:8080/ prokPUB/chaprender/jsp/showchap.jsp?chapnum =355).

Heckmann, K. \& Schmidt, H. J. (1987). Polynucleobacter necessarius gen. nov., sp. nov., an obligately endosymbiotic bacterium living in the cytoplasm of Euplotes aediculatus. Int J Syst Bacteriol 37, 456-457.

Heckmann, K., den Hagen, R. \& Görtz, H. D. (1983). Fresh-water Euplotes species with a 9 type 1 cirrus pattern depend upon endosymbionts. J Protozool 30, 284-289.

Ludwig, W. \& Strunk, O. (1997). ARB: a software environment for sequence data (http://www.arb-home.de/).

Ludwig, W. \& Klenk, H.-P. (2001). Overview: a phylogenetic backbone and taxonomic framework for procaryotic systematics. In Bergey's Manual of Systematic Bacteriology, $2^{\text {nd }}$ edn, pp. 49-65. Edited by D. R. Boone, R. W. Castenholz \& G. M. Garrity. New York: Springer.

Ludwig, W., Amann, R., Martinez-Romero, E., Schönhuber, W., Bauer, S., Neef, A. \& Schleifer, K.-H. (1998a). rRNA based identification and detection systems for rhizobia and other bacteria. Plant Soil 204, 1-19.

Ludwig, W., Strunk, O., Klugbauer, S., Klugbauer, N., Weizenegger, M., Neumaier, J., Bachleitner, M. \& Schleifer, K. H. (1998b). Bacterial phylogeny based on comparative sequence analysis. Electrophoresis 19, 554-568.

Manz, W., Amann, R. I., Ludwig, W., Wagner, M. \& Schleifer, K. H. (1992). Phylogenetic oligodeoxynucleotide probes for the major subclasses of proteobacteria: problems and solutions. Syst Appl Microbiol 15, 593-600.

Medlin, L., Elwood, H. J., Stickel, S. \& Sogin, M. L. (1988). The characterization of enzymatically amplified eukaryotic 16S-like rRNA-coding regions. Gene 71, 491-499.

Modeo, L., Petroni, G., Rosati, G. \& Montagnes, D. J. (2003). A multidisciplinary approach to describe protists: redescriptions of Novistrombidium testaceum Anigstein 1914 and Strombidium inclinatum Montagnes, Taylor, and Lynn 1990 (Ciliophora, Oligotrichia). J Eukaryot Microbiol 50, 175-189.

Murray, R. G. E. \& Schleifer, K. H. (1994). Taxonomic notes: a proposal for recording the properties of putative taxa of procaryotes. Int J Syst Bacteriol 44, 174-176.

Murray, R. G. E. \& Stackebrandt, E. (1995). Taxonomic note: implementation of the provisional status Candidatus for incompletely described procaryotes. Int J Syst Bacteriol 45, 186-187.

Nakagawa, Y., Sakane, T. \& Yokota, A. (1996). Transfer of "Pseudomonas riboflavina" (Foster 1944), a gram-negative, motile rod with long-chain 3-hydroxy fatty acids, to Devosia riboflavina gen. nov., sp. nov., nom. rev. Int J Syst Bacteriol 46, 16-22.

Nobili, R., Rosati, G. \& Verni, F. (1976). The killer trait in Euplotes crassus (Ciliata, Hypotrichida). Boll Zool 43, 251-258.

Petroni, G., Spring, S., Schleifer, K. H., Verni, F. \& Rosati, G. (2000). Defensive extrusive ectosymbionts of Euplotidium (Ciliophora) that 
contain microtubule-like structures are bacteria related to Verrucomicrobia. Proc Natl Acad Sci U S A 97, 1813-1817.

Petroni, G., Dini, F., Verni, F. \& Rosati, G. (2002). A molecular approach to the tangled intrageneric relationships underlying phylogeny in Euplotes (Ciliophora, Spirotrichea). Mol Phylogenet Evol 22, 118-130.

Petroni, G., Rosati, G., Vannini, C., Modeo, L., Dini, F. \& Verni, F. (2003). In situ identification by fluorescently labeled oligonucleotide probes of morphologically similar, closely related ciliate species. Microb Ecol 45, 156-162.

Preer, J. R., Jr \& Preer, L. B. (1982). Revival of names of protozoan endosymbionts and proposal of Holospora caryophila nom. nov. Int J Syst Bacteriol 32, 140-141.

Preer, J. R., Jr, Preer, L. B. \& Jurand, A. (1974). Kappa and other endosymbionts in Paramecium aurelia. Bacteriol Rev 38, 113-163.

Quackenbush, R. L. (1982). Pseudocaedibacter gen. nov. In Validation of the Publication of New Names and New Combinations Previously Effectively Published Outside the IJSB, List no. 8. Int J Syst Bacteriol 32, 266-268.

Rivas, R., Velázquez, E., Willems, A., Vizcaíno, N., Subba-Rao, N. S., Mateos, P. F., Gillis, M., Dazzo, F. B. \& Martínez-Molina, E. (2002). A new species of Devosia that forms a unique nitrogen-fixing rootnodule symbiosis with the aquatic legume Neptunia natans (L.f.) Druce. Appl Environ Microbiol 68, 5217-5222.

Rivas, R., Willems, A., Subba-Rao, N. S., Mateos, P. F., Dazzo, F. B., Kroppenstedt, R. M., Martínez-Molina, E., Gillis, M. \& Velázquez, E. (2003). Description of Devosia neptuniae sp. nov. that nodulates and fixes nitrogen in symbiosis with Neptunia natans, an aquatic legume from India. Syst Appl Microbiol 26, 47-53.
Rosati, G., Verni, F. \& Luporini, P. (1976). Cytoplasmic bacteria-like endosymbionts in Euplotes crassus (Dujardin) (Ciliata Hypotrichida). Monit Zool Ital 10, 449-460.

Rosati, G., Modeo, L., Melai, M., Petroni, G. \& Verni, F. (2004). A multidisciplinary approach to describe protists: a morphological, ultrastructural, and molecular study on Peritromus kahli VilleneuveBrachon, 1940 (Ciliophora, Heterotrichea). J Eukaryot Microbiol 51, 49-59.

Rosselló-Mora, R. \& Amann, R. (2001). The species concept for prokaryotes. FEMS Microbiol Rev 25, 39-67.

Springer, N., Ludwig, W., Amann, R., Schmidt, H. J., Görtz, H.-D. \& Schleifer, K.-H. (1993). Occurrence of fragmented 16S rRNA in an obligate bacterial endosymbiont of Paramecium caudatum. Proc Natl Acad Sci U S A 90, 9892-9895.

Springer, N., Amann, R., Ludwig, W., Schleifer, K.-H. \& Schmidt, H. (1996). Polynucleobacter necessarius, an obligate bacterial endosymbiont of the hypotrichous ciliate Euplotes aediculatus, is a member of the $\beta$-subclass of Proteobacteria. FEMS Microbiol Lett 135, 333-336.

Stackebrandt, E. (2000). Defining taxonomic ranks. In The Prokaryotes: an Evolving Electronic Resource for the Microbiological Community, 3rd edn (http://141.150.157.117:8080/prokPUB/ chaprender/jsp/showchap.jsp?chapnum $=240$ ).

Stahl, D. A. \& Amann, R. (1991). Development and application of nucleic acid probes. In Nucleic Acid Techniques in Bacterial Systematics, pp. 205-248. Edited by E. Stackebrandt \& M. Goodfellow. Chichester, UK: Wiley.

Wisotzkey, J. D., Jurtshuk, P., Jr \& Fox, G. E. (1990). PCR amplification of $16 \mathrm{~S}$ rDNA from lyophilized cell cultures facilitates studies in molecular systematics. Curr Microbiol 21, 325-327. 